University of Wollongong

Research Online

Faculty of Social Sciences - Papers (Archive) Faculty of Arts, Social Sciences \& Humanities

2010

The relationship of cardiorespiratory fitness, birth weight and parental BMI

on adolescents obesity status

Susana Vale

Universidade do Porto

Rute Santos

University of Wollongong, rutes@uow.edu.au

Luisa Soares-Miranda

Universidade do Porto

Jorge Mota

Universidade do Porto

Follow this and additional works at: https://ro.uow.edu.au/sspapers

Part of the Education Commons, and the Social and Behavioral Sciences Commons

Research Online is the open access institutional repository for the University of Wollongong. For further information contact the UOW Library: research-pubs@uow.edu.au 


\title{
The relationship of cardiorespiratory fitness, birth weight and parental BMI on adolescents obesity status
}

\author{
Abstract \\ Background/Objectives: \\ The aims of this study were as follows: (1) to analyze differences in cardiorespiratory fitness (CRF), \\ parents' body mass index (BMI) and birth weight (BW) between non-overweight (NOW) and overweight/ \\ obese (OV/OB) adolescents, and (2) to investigate the association of those variables with the risk of their \\ biological offspring being OV/OB.
}

\section{Subjects/Methods:}

This study comprised 788 adolescents ( 477 girls and 311 boys), aged between 12 and 18 years. CRF was predicted by maximal multistage 20 -m shuttle-run test according to the procedures described in FITNESSGRAM. Children's BMI was classified according to the International Obesity Task Force. Adolescents' BW was assessed from each child's pediatric record at birth. Parents' OV/OB status was defined and classified according to the World Health Organization. Socioeconomic status was defined by parental education.

\section{Results:}

The prevalence OV/OB was 21.4 and $5.3 \%$, respectively, and there were no gender differences. The OV/OB adolescents (girls and boys) had significantly $(P \leq 0.05)$ lower CRF scores and higher BW $(P \leq 0.05)$ than did the NOW pears. Overall, $92.9 \%$ of OV/OB girls had one or two parents with OV/OB $(P \leq 0.05)$. Boys with low CRF (odds ratio (OR): $3.75 ; P \leq 0.05$ ) and high BW (OR: $1.65 ; P \leq 0.05)$ were more likely to be classified as OV/OB compared with NOW. Girls with low CRF (OR: 2.66; $P \leq 0.05$ ), high BW (OR: $2.09 ; P \leq 0.05)$ and at least one parent (OR: 2.28; $P \leq 0.05$ ) or two parents with OV/OB (OR: 4.39; $P \leq 0.05$, respectively) were classified as OV/OB.

\section{Conclusions:}

Results from this study highlight the association between the family adolescents' obesity, in girls. Furthermore, our data suggested that low CRF and high BW were strong predictors of OV/OB in adolescence.

\section{Keywords}

weight, birth, fitness, status, obesity, cardiorespiratory, adolescents, relationship, bmi, parental

\section{Disciplines}

Education | Social and Behavioral Sciences

\section{Publication Details}

Vale, S., Santos, R., Soares-Miranda, L. \& Mota, J. (2010). The relationship of cardiorespiratory fitness, birth weight and parental BMI on adolescents obesity status. European Journal of Clinical Nutrition, 64 (6), 622-627. 


\title{
Original Research
}

\section{The Relationship of Cardiorespiratory Fitness, Birth Weight, and Parental BMI on Adolescents' Obesity Status.}

\author{
Susana Maria Coelho Guimarães Vale (MS)* - susanavavale@hotmail.com \\ Rute Marina Roberto Santos (PhD)* - rutemarinasantos@hotmail.com \\ Luísa Maria da Cruz Soares-Miranda (Grad)* - luisasoaresmiranda@hotmail.com \\ Jorge Augusto Silva Mota (PhD)* - jmota@fade.up.pt \\ *Research Centre in Physical Activity, Health and Leisure. Faculty of Sport - University of Porto
}

\section{Author's Address:}

Susana Vale

Research Centre in Physical Activity, Health and Leisure

Faculty of Sports - University of Porto

R. Plácido Costa, 91

4200-450

Porto - Portugal

Phone:351-22-5074786

Fax: 351-22-5500689

Email: susanavale@hotmail.com

Running Title: Influence of Fitness and Anthropometry in Obesity

Research was supported by Foundation of Science and Technology - SFRH/BD/30059/2006. 


\begin{abstract}
Background/ Objectives: The aims of this study was (1) to analyze differences in cardio respiratory fitness (CRF), parents' body mass index (BMI) and birth weight (BW) between non-overweight (NOW) and overweight/obese (OV/OB) adolescents, and (2) to investigate the association of those variables with the risk of their biological offspring being OVIOB.
\end{abstract}

Subjects/ Methods: This study comprised 788 adolescents (477 girls and 311 boys), aged from 12-18 years old. CRF was predicted by maximal multistage $20 \mathrm{~m}$ shuttle-run test according to procedures described in FITNESSGRAM. Children's BMI was classified according to International Obesity Task Force. Adolescent's BW was assessed by each child's pediatric record at birth. Parent's OV/OB status was defined and classified according to WHO. Socioeconomic status was defined by parental education.

Results: The prevalence OV/OB was $21.4 \%$ and $5.3 \%$, respectively and there were no gender differences. The OV/OB adolescents (girls and boys) had significantly $(p \leq 0.05)$ lower CRF scores and higher BW $(p \leq 0.05)$ than the NOW pears. $92.9 \%$ of OV/OB girls had one or two parents with OV/OB ( $p \leq 0.05)$. Boys with low CRF (OR: $3.75 ; p \leq 0.05)$ and high BW (OR: 1.65; $\mathrm{p} \leq 0.05)$ were more likely to be classified as OV/OB compared with NOW. Girls with low CRF (OR: 2.66; $p \leq 0.05$ ), high BW (OR: 2.09; $p \leq 0.05$ ) and at least one parent (OR: 2.28; $p \leq 0.05$ ) or two parents with OV/OB (OR: 4.39; $p \leq 0.05$, respectively) were associated with being OV/OB.

Conclusions: Results from this study highlight association between the family adolescents' obesity, in girls. Further our data suggested that low CRF and high BW were strong predictors of OV/OB in adolescence.

Keys words: Adolescents; Obesity Status; Cardiorespiratory Fitness, Birth Weight, Parental BMI 


\section{Introduction}

The prevalence of childhood obesity has been rising during the past decades in many parts of the world (WHO, 2000). Previous studies have shown an high prevalence of overweight and obesity in Portuguese young children (Padez et al., 2004) and adolescents (Ribeiro et al., 2003). Because the onset of obesity lies in early childhood, it is of great importance to examine the risk trends in order that effective preventive strategies targeting those at risk start as early as possible.

The origin of obesity is complex and is influenced by genetic and environmental factors. For instance, it has been shown that obese parents offspring's have a higher risk of obesity due to shared genes and shared environments (Gordon-Larsen et al., 2000). Indeed, fatness tends to aggregate within families (Garn et al., 1989) as a result of relations among genetic and environmental factors (Borecki et al., 1993, Faith et al., 1997) and increases the risk that a child will become an obese adult, (Magarey et al., 2003, Lake et al., 1997) independent of fatness status in childhood (Whitaker et al., 1997).

Birth weight (BW) has also been reported as an important marker of genetic factors and intrauterine environment related with increased obesity prevalence. Some studies have demonstrated associations between fetal experiences and later risk for adult cardiovascular and other chronic diseases (Hales and Barker, 2001, Karter et al., 1999). Conversely, Wei et al. (2007) in a recent study showed that higher BW was associated with youth obesity and

diabetes. It is also known that obesity during the pre-school years was associated with other clinical factors easily assessed at birth (Baird et al., 2005). For instance, it was found an association between BW and the risk to be obese in children at the age of 4, 8, 10 and 12 years old (Maffeis et al., 1994), while a high BW was associated with higher BMI at age of 7 years (Toschke et al., 2004, Hui et al., 2008).

On the other hand, the epidemic of overweight likely involves changes in the balance between energy intake and energy expenditure. Indeed, patterns of physical activity; sedentary living and diet, appear to play an important role in long-term weight regulation (Bouchard, 2000). Besides, low physical fitness, especially low cardiorespiratory fitness (CRF) showed a significant and inverse relationship with body fatness in a large number of studies (Kim et al., 2005, Mota et al., 2006, Deforche et al., 2003). This highlights the importance of increasing 
CRF for a protective effect in early ages since there are some evidences that CRF levels tracked from childhood and adolescence into adulthood (Hasselstrom et al., 2002). Persons who are physically fit maintain a more favourable caloric balance and lower body weights, both of which protect against the development of cardiovascular disease risk factors (Carnethon et al., 2003).

Despite that, the relationship of adolescence obesity with BW and CRF were not found consistently (Gibson et al., 2006), especially when parental characteristics were taken into account (McMurray et al., 2000, Francis et al., 2003).

Therefore, the aims of this study were (1) to analyze differences in CRF fitness, parents' $\mathrm{BMI}$ and BW between non-overweight (NOW) and overweight/obese (OV/OB) adolescents, and (2) to investigate the association of those variables with the risk of their biological offspring being OVIOB.

\section{Methods}

\section{Participants and data collection}

This is a cross-sectional study carried out in two middle and high suburban schools comprising of all the students registered in $7^{\text {th }}$ to $12^{\text {th }}$ grade during $2006 / 2007$ academic year. A letter informing families that students will be measured was sent home two weeks before measurements took place. This study was conducted according to the guidelines of the Helsinki Declaration of Human Studies. Written given consent was required. The Portuguese Foundation for Science and Technology provided permission to conduct this study.

This study was comprised of 788 students (477 girls and 311 boys), aged 12-18 years old along with their parents. The questionnaires were distributed and filled out during physical education classes. Data collection was also obtained by mailing questionnaires to adolescents' parents.

\section{Anthropometric Measures}

Body height was measured to the nearest millimetre in bare or stocking feet with the adolescent standing upright against a Holtain stadiometer. Weight was measured to the nearest $0.10 \mathrm{~kg}$, lightly dressed using an electronic weight scale (Seca 708 portable digital beam scale). 
Body Mass Index (BMI) was calculated from the ratio of body weight $(\mathrm{kg})$ to body height $\left(\mathrm{m}^{2}\right)$. For purposes of this study, participants were classified as either NOW or OVIOB based on the International Obesity Task Force (Cole et al., 2000). Parents' BMI was calculated from selfreport weight and height and used to evaluate weight status according to WHO recommendations. BMI was divided into three categories: normal weight $\left(18.5 \mathrm{~kg} / \mathrm{m}^{2} \geq \mathrm{BMI}<25\right.$ $\left.\mathrm{kg} / \mathrm{m}^{2}\right)$; overweight $\left(25 \mathrm{~kg} / \mathrm{m}^{2} \geq \mathrm{BMl}<30 \mathrm{~kg} / \mathrm{m}^{2}\right)$ and obese $\left(\mathrm{BMl} \geq 30 \mathrm{~kg} / \mathrm{m}^{2}\right)(\mathrm{WHO}, 1998)$. Further, for the analysis of the associations between adolescents obesity with parental characteristics, parents were further divided into three groups: (1) both parents with normalweight; (2) one overweight/obese parent, and (3) both parents OVIOB.

Adolescents' BW was assessed from each child's pediatric record at birth.

\section{Cardiorespiratory Fitness (CRF)}

CRF was measured using the $20-\mathrm{m}$ shuttle run test (20mSRT) as previously described by Léger et al (1988). This test requires subjects to run back and forth between two lines set $20 \mathrm{~m}$ apart. Before testing, the tape was checked for accuracy. Running speed started at $8.5 \mathrm{~km} / \mathrm{h}$ and increased by $0.5 \mathrm{~km} / \mathrm{h}$ each minute, reaching $18.0 \mathrm{~km} / \mathrm{h}$ at minute 20. Each level was announced on the tape. The participants were told to keep up with the pacer until exhausted. The test was finished when the participant failed to reach the end lines concurrent with the audio signals on two consecutive occasions. Otherwise, the test ended when the subject stopped because of fatigue. Participants were encouraged to keep running as long as possible throughout the course of the test. Numbers of shuttles performed were recorded. Participants were then classified according to the age and sex-specific cut-off points of Fitnessgram 8.0 criteria, as belonging to a healthy zone or under health zone.

\section{Socioeconomic status}

The highest school education achieved by either mother or father was used to define social class (Parental Education). Single parent families were included, and these children were classified according to school education of the single parent. Parental Education was defined based upon Portuguese Educational system [(1) 9 years' education or less- sub secondary 
level; (2) 10-12 years' education-secondary level and (3) higher education)] and then assigned into three groups (1=Low (LE); $2=$ Middle $(\mathrm{ME})$ and $3=$ High $(\mathrm{HE})$ level of education, respectively). Similar procedures have been applied in the Portuguese context (Mota and Silva, 1999).

\section{Statistics}

Means and standard deviations were calculated to describe participants' characteristics by gender and obesity status. The comparisons between genders and obesity status were done by independent t-test for anthropometric variables and chi-square test for BMI categories, CRF, parental BMI and parental education. For both genders, the independent association of predictors with BMI as dependent variable (Non-Overweight and Overweight/Obese) was examined using stepwise logistic regression analysis with age, birth weight, parental obesity status and parental education as independent variables. Statistical analysis was performed using SPSS 15 software (SPSS Inc., Chicago, IL, USA) and Microsoft Excel 2000. The level of significance was set at $p \leq 0.05$.

\section{Results}

Table I shows descriptive statistics (mean and SD) of adolescents and parents by gender. Boys were taller, heavier, had higher BW and CRF than girls $(p \leq 0.05)$, while girls were older. No statistical significant differences were found with regard to the BMI. The overall prevalence of overweight and obesity was $21.4 \%$ and $5.3 \%$, respectively. No statistical significant differences between genders were found. A higher $(p \leq 0.05)$ proportion of girls $(49.9 \%)$ were classified as unfit than boys $(35.7 \%)$ were. Fifty three percent of fathers were classified as overweight while $15 \%$ were classified as obese. For mothers the numbers were $\mathbf{3 6 . 6 \%}$ for overweight and $\mathbf{1 3 . 4 \%}$ for obese, respectively.

Insert Table 1

Table 2 shows differences within genders according to obesity status for the variables under study. Regardless of gender the OV/OB group was significantly heavier, had higher BMI 
and BW and had both parents with high BMI values than their NOW peers. CRF values (numbers of laps) were significantly lower in OV/OB than in NOW group. A statistically higher $(\mathrm{p} \leq 0.05)$ proportion of OV/OB girls $(61.4 \%)$ and boys $(54.8 \%)$ were assigned to the under health zone (unfit) compared to their lean counterparts. Parental BMI differed between NOW and OV/OB only in girls $(p \leq 0.05)$. No statistical significant differences were found regarding parental education.

Insert Table 2

Stepwise logistic regression analysis (Figure 1) showed that boys with low CRF (OR: 3.75; Cl: 2.14-6.59; $\mathrm{p} \leq 0.05)$ and high BW (OR: 1.65; Cl: 1.02-2.67; $\mathrm{p} \leq 0.05)$ were more likely to be classified as OV/OB compared with NOW peers. Girls with low CRF (OR: 2.66; Cl: 1.644.32; $p \leq 0.05$ ), high BW (OR: 2.09; $\mathrm{Cl}: 1.36-3.24 ; p \leq 0.05)$ and with at least one parent with OV/OB (OR: 2.28; Cl: 1.05-4.95; p $\leq 0.05$ ) or two parents with OV/OB (OR: 4.39; Cl: 1.99-9.64; $p \leq 0.05)$ were more likely to be classified as OV/OB compared with NOW peers.

\section{Insert Figure 1}

\section{Discussion}

This paper examined the association between CRF and obesity status in adolescents taking into account BW, parental BMI and education. Prevalence of overweight and obesity in the present study was $21.4 \%$ and $5.3 \%$ for the whole samples. Although participants were not country representative, the prevalence of overweight and obesity was similar to values reported in other samples of Portuguese youth (Ribeiro et al., 2003, Padez et al., 2004). This prevalence values found in our study must be highlighted because our data also showed that the percentage of $\mathrm{OV} / \mathrm{OB}$ adolescents at risk of CRF (under health zone) was significantly higher $(p \leq 0.05)$ compared to NOW peers. Although the overall percentage of adolescents at risk for CRF is in line with the one described in Irish adolescents (Boreham et al., 1993) and our data agreed with another study showing that boys reached the CRF health zones criterion than girls (Riddoch et al., 2004). Our results might have some importance from a preventive 
point of view because they potentially pointed out some future health negative implications. Indeed, there are evidences showing that low levels of CRF associated with excess body fat and sedentary daily life are significant predictors of developing heart disease (Janssen et al., 2005) as well as suggesting the health impact of small increases in youth with lower fitness levels (Klasson-Heggebo et al., 2006). Thus, since tracking obesity (Dietz, 2004, Guo et al., 2002) and CRF (Janz and Mahoney, 1997, Twisk et al., 2000) from childhood to adulthood has been described and a secular decreasing trend of CRF has also been found (Martins et al., 2008). Our findings raised concerns with regard to those whom are classified as OV/OB and unfit, which has already been pointed out previously (Pate et al., 2006).

Furthermore, the major finding of this study was that parent obesity was a strong predictor of adolescents OV/OB girls and not in boys. Although some studies showed an association between parents' obesity level and their offspring obesity status (Whitaker et al., 1997, Maffeis et al., 1998, Treuth et al., 2003), our data highlighted the association of parents' $\mathrm{BMI}$ and their daughter. This has already been suggested in another survey showing that the number of overweight parents predicted fat gain among normal weight girls (Treuth et al., 2003). Furthermore our data clearly showed that association was even stronger when obesity was found in both, rather than in only one parent, which agrees with other studies (Davison and Birch, 2001, Herbert et al., 2006). For instance, having an obese mother was associated with earlier age at obesity onset (Gordon-Larsen et al., 2007). This is particularly worthy because some data suggested that an overweight child living in a family where one or more parents are overweight is likely to remain overweight throughout his or her childhood and into adolescence and adulthood (Magarey et al., 2003). Therefore our data suggested that adolescents' BMI status in girls, but not in boys, is likely to reflect the fact that childhood overweight/obesity occurs within a family context, in which environmental factors besides genetic factors played an important role. Thus, our data suggests, the need of taking the family environment into consideration when designing intervention programs, especially in girls.

Several studies have addressed the association between BW and late development of cardiovascular diseases (Karter et al., 1999, Wei et al., 2007) and obesity (Stettler et al., 2002). Our data demonstrated that high BW girls had two times higher odds of being OW/OB, while boys had 1.65 times higher odds of being classified as OWIOB, which is consistent with other 
studies showing a positive association between BW and further prevalence of obesity in both children a adolescents (Curhan et al., 1996, Dubois and Girard, 2006, Wei et al., 2007). Therefore, our data showed that regardless of gender high BW was a strong predictor of being $O V I O B$ in adolescence and, thus, strategy options should be taken into consideration with regard to the intrauterine factors.

Strengths of this study included the large sample size and response rate of parents as well as measures of socioeconomic status. This study has also some limitations that should be acknowledged. First, our parental BMI are based on self-report data, which could indicate an underestimation of the true prevalence of overweight and obesity (Yun et al., 2006). Nevertheless, BMI from self-report data was found to be sufficiently accurate and widely used in epidemiological studies, on the other hand objective measurements of weight and height in large samples can be difficult and unattainable. Second, dietary factors weren't assessed and it is well known the influence of diet on energy regulation. Further studies should also consider the nutritional factors that might be related to obesity.

\section{Conclusion}

Results from this study highlight association between the family adolescents' obesity, in girls. Further our data suggested that low CRF and high BW were strong predictors of OV/OB in adolescence.

\section{Acknowledgements}

This study was supported by Foundation of Science and Technology FCT/SFRH/BD/30059/2006.

\section{Conflict of I nterest}

The authors declare no conflict of interest.

\section{References}

BAIRD, J., FISHER, D., LUCAS, P., KLEIJNEN, J., ROBERTS, H. \& LAW, C. 2005. Being big or growing fast: systematic review of size and growth in infancy and later obesity. BMJ, 331, 929. 
BORECKI, I. B., BONNEY, G. E., RICE, T., BOUCHARD, C. \& RAO, D. C. 1993. Influence of genotype-dependent effects of covariates on the outcome of segregation analysis of the body mass index. Am J Hum Genet, 53, 676-87.

BOREHAM, C., SAVAGE, J. M., PRIMROSE, D., CRAN, G. \& STRAIN, J. 1993. Coronary risk factors in schoolchildren. Arch Dis Child, 68, 182-6.

BOUCHARD, C. 2000. The obesity epidemic: Introduction. In: KINETICS, H. (ed.) Physical Activity and Obesity. Champaign, IL.

CARNETHON, M. R., GIDDING, S. S., NEHGME, R., SIDNEY, S., JACOBS, D. R., JR. \& LIU, K. 2003. Cardiorespiratory fitness in young adulthood and the development of cardiovascular disease risk factors. JAMA, 290, 3092-100.

COLE, T., BELLIZZI, M., FLEGAL, K. \& DIETZ, W. 2000. Establishing a standard definition for child overweight and obesity worldwide: international survey. Bmj, 320, 1240-3.

CURHAN, G. C., CHERTOW, G. M., WILlETT, W. C., SPIEGELMAN, D., COLDITZ, G. A., MANSON, J. E., SPEIZER, F. E. \& STAMPFER, M. J. 1996. Birth weight and adult hypertension and obesity in women. Circulation, 94, 1310-5.

DAVISON, K. K. \& BIRCH, L. L. 2001. Child and parent characteristics as predictors of change in girls' body mass index. Int J Obes Relat Metab Disord, 25, 183442.

DEFORCHE, B., LEFEVRE, J., DE BOURDEAUDHUIJ, I., HILLS, A. P., DUQUET, W. \& BOUCKAERT, J. 2003. Physical fitness and physical activity in obese and nonobese Flemish youth. Obes Res, 11, 434-41.

DIETZ, W. H. 2004. Overweight in childhood and adolescence. $N$ Engl J Med, 350, 855-7.

DUBOIS, L. \& GIRARD, M. 2006. Early determinants of overweight at 4.5 years in a population-based longitudinal study. Int J Obes (Lond), 30, 610-7.

FAITH, M. S., JOHNSON, S. L. \& ALLISON, D. B. 1997. Putting the behavior into the behavior genetics of obesity. Behav Genet, 27, 423-39.

FRANCIS, L. A., LEE, Y. \& BIRCH, L. L. 2003. Parental weight status and girls' television viewing, snacking, and body mass indexes. Obes Res, 11, 143-51.

GARN, S. M., SULLIVAN, T. V. \& HAWTHORNE, V. M. 1989. Fatness and obesity of the parents of obese individuals. Am J Clin Nutr, 50, 1308-13.

GIBSON, L. J., PETO, J., WARREN, J. M. \& DOS SANTOS SILVA, I. 2006. Lack of evidence on diets for obesity for children: a systematic review. Int J Epidemiol, 35, 1544-52.

GORDON-LARSEN, P., ADAIR, L. S. \& SUCHINDRAN, C. M. 2007. Maternal obesity is associated with younger age at obesity onset in U.S. adolescent offspring followed into adulthood. Obesity (Silver Spring), 15, 2790-6.

GORDON-LARSEN, P., MCMURRAY, R. G. \& POPKIN, B. M. 2000. Determinants of adolescent physical activity and inactivity patterns. Pediatrics, 105, E83.

GUO, S. S., WU, W., CHUMLEA, W. C. \& ROCHE, A. F. 2002. Predicting overweight and obesity in adulthood from body mass index values in childhood and adolescence. Am J Clin Nutr, 76, 653-8.

HALES, C. N. \& BARKER, D. J. 2001. The thrifty phenotype hypothesis. Br Med Bull, 60, 5-20.

HASSELSTROM, H., HANSEN, S. E., FROBERG, K. \& ANDERSEN, L. B. 2002. Physical fitness and physical activity during adolescence as predictors of cardiovascular disease risk in young adulthood. Danish Youth and Sports Study. An eight-year follow-up study. Int J Sports Med, 23 Suppl 1, S27-31. 
HERBERT, A., GERRY, N. P., MCQUEEN, M. B., HEID, I. M., PFEUFER, A., ILLIG, T., WICHMANN, H. E., MEITINGER, T., HUNTER, D., HU, F. B., COLDITZ, G., HINNEY, A., HEBEBRAND, J., KOBERWITZ, K., ZHU, X., COOPER, R., ARDLIE, K., LYON, H., HIRSCHHORN, J. N., LAIRD, N. M., LENBURG, M. E., LANGE, C. \& CHRISTMAN, M. F. 2006. A common genetic variant is associated with adult and childhood obesity. Science, 312, 279-83.

HUI, L. L., SCHOOLING, C. M., LEUNG, S. S., MAK, K. H., HO, L. M., LAM, T. H. \& LEUNG, G. M. 2008. Birth weight, infant growth, and childhood body mass index: Hong Kong's children of 1997 birth cohort. Arch Pediatr Adolesc Med, 162, 212-8.

JANSSEN, I., KATZMARZYK, P. T., BOYCE, W. F., VEREECKEN, C., MULVIHILL, C., ROBERTS, C., CURRIE, C. \& PICKETT, W. 2005. Comparison of overweight and obesity prevalence in school-aged youth from 34 countries and their relationships with physical activity and dietary patterns. Obes Rev, 6, 123-32.

JANZ, K. F. \& MAHONEY, L. T. 1997. Three-year follow-up of changes in aerobic fitness during puberty: the Muscatine Study. Res Q Exerc Sport, 68, 1-9.

KARTER, A. J., ROWELL, S. E., ACKERSON, L. M., MITCHELL, B. D., FERRARA, A., SELBY, J. V. \& NEWMAN, B. 1999. Excess maternal transmission of type 2 diabetes. The Northern California Kaiser Permanente Diabetes Registry. Diabetes Care, 22, 938-43.

KIM, J., MUST, A., FITZMAURICE, G. M., GILLMAN, M. W., CHOMITZ, V., KRAMER, E., MCGOWAN, R. \& PETERSON, K. E. 2005. Relationship of physical fitness to prevalence and incidence of overweight among schoolchildren. Obes Res, 13, 1246-54.

KLASSON-HEGGEBO, L., ANDERSEN, L. B., WENNLOF, A. H., SARDINHA, L. B., HARRO, M., FROBERG, K. \& ANDERSSEN, S. A. 2006. Graded associations between cardiorespiratory fitness, fatness, and blood pressure in children and adolescents. Br J Sports Med, 40, 25-9; discussion 25-9.

LAKE, J. K., POWER, C. \& COLE, T. J. 1997. Child to adult body mass index in the 1958 British birth cohort: associations with parental obesity. Arch Dis Child, 77, 376-81.

LEGER, L. A., MERCIER, D., GADOURY, C., LAMBERT, J. 1988. The multistage 20 meter shuttle run test for aerobic fitness. J Sports Sci, 6, 93-101.

MAFFEIS, C., MICCIOLO, R., MUST, A., ZAFFANELLO, M. \& PINELLI, L. 1994. Parental and perinatal factors associated with childhood obesity in north-east Italy. Int J Obes Relat Metab Disord, 18, 301-5.

MAFFEIS, C., TALAMINI, G. \& TATO, L. 1998. Influence of diet, physical activity and parents' obesity on children's adiposity: a four-year longitudinal study. Int $J$ Obes Relat Metab Disord, 22, 758-64.

MAGAREY, A. M., DANIELS, L. A., BOULTON, T. J. \& COCKINGTON, R. A. 2003. Predicting obesity in early adulthood from childhood and parental obesity. Int J Obes Relat Metab Disord, 27, 505-13.

MARTINS, C., SILVA, F., SANTOS, M. P., RIBEIRO, J. C. \& MOTA, J. 2008. Trends of cardiovascular risk factors clustering over time: a study in two cohorts of Portuguese adolescents. Pediatr Exerc Sci, 20, 74-83.

MCMURRAY, R. G., HARRELL, J. S., DENG, S., BRADLEY, C. B., COX, L. M. \& BANGDIWALA, S. I. 2000. The influence of physical activity, socioeconomic status, and ethnicity on the weight status of adolescents. Obes Res, 8, 130-9. 
MOTA, J., FLORES, L., RIBEIRO, J. C. \& SANTOS, M. P. 2006. Relationship of single measures of cardiorespiratory fitness and obesity in young schoolchildren. Am J Hum Biol, 18, 335-41.

MOTA, J. \& SILVA, G. 1999. Adolescent`s physical activity with socio-economic status and parental participation among a Portuguese sample. Sport, education and Society, 4, 193-199.

PADEZ, C., FERNANDES, T., MOURAO, I., MOREIRA, P. \& ROSADO, V. 2004. Prevalence of overweight and obesity in 7-9-year-old Portuguese children: trends in body mass index from 1970-2002. Am J Hum Biol, 16, 670-8.

PATE, R. R., ALMEIDA, M. J., MCIVER, K. L., PFEIFFER, K. A. \& DOWDA, M. 2006. Validation and calibration of an accelerometer in preschool children. Obesity (Silver Spring), 14, 2000-6.

RIBEIRO, J., GUERRA, S., PINTO, A., DUARTE, J. \& MOTA, J. 2003. Prevalencia de excesso de peso e de obesidade numa populaçao escolar da area do grande Porto, de acordo com diferentes pontos de corte do indice de massa corporal. Acta Pediatrica Portuguesa, 34, 21-24.

RIDDOCH, C. J., BO ANDERSEN, L., WEDDERKOPP, N., HARRO, M., KLASSON-HEGGEBO, L., SARDINHA, L. B., COOPER, A. R. \& EKELUND, U. 2004. Physical activity levels and patterns of 9- and 15-yr-old European children. Med Sci Sports Exerc, 36, 86-92.

STETTLER, N., ZEMEL, B. S., KUMANYIKA, S. \& STALLINGS, V. A. 2002. Infant weight gain and childhood overweight status in a multicenter, cohort study. Pediatrics, 109, 194-9.

TOSCHKE, A. M., GROTE, V., KOLETZKO, B. \& VON KRIES, R. 2004. Identifying children at high risk for overweight at school entry by weight gain during the first 2 years. Arch Pediatr Adolesc Med, 158, 449-52.

TREUTH, M. S., BUTTE, N. F. \& SORKIN, J. D. 2003. Predictors of body fat gain in nonobese girls with a familial predisposition to obesity. Am J Clin Nutr, 78, 1212-8.

TWISK, J. W., KEMPER, H. C. \& VAN MECHELEN, W. 2000. Tracking of activity and fitness and the relationship with cardiovascular disease risk factors. Med Sci Sports Exerc, 32, 1455-61.

WEI, J. N., LI, H. Y., SUNG, F. C., LIN, C. C., CHIANG, C. C., LI, C. Y. \& CHUANG, L. M. 2007. Birth weight correlates differently with cardiovascular risk factors in youth. Obesity (Silver Spring), 15, 1609-16.

WHITAKER, R. C., WRIGHT, J. A., PEPE, M. S., SEIDEL, K. D. \& DIETZ, W. H. 1997. Predicting obesity in young adulthood from childhood and parental obesity. $N$ Engl J Med, 337, 869-73.

WHO 1998. Obesity: preventing and managing the global epidemic. 1-278.

WHO 2000. Obesity: Preventing and managing the global epidemic.

YUN, S., ZHU, B. P., BLACK, W. \& BROWNSON, R. C. 2006. A comparison of national estimates of obesity prevalence from the behavioral risk factor surveillance system and the National Health and Nutrition Examination Survey. Int $J$ Obes (Lond), 30, 164-70. 
Figure 1 - Prevalence of Overweight and Obesity by stepwise multiple logistic regression analysis in each gender. 
Table 1 - Sample Characteristics

\begin{tabular}{|c|c|c|c|c|c|}
\hline \multicolumn{2}{|c|}{ Characteristics } & $\begin{array}{l}\text { Total } \\
(n=788)\end{array}$ & $\begin{array}{l}\text { Girls } \\
(n=477)\end{array}$ & $\begin{array}{l}\text { Boys } \\
(n=311)\end{array}$ & $\mathrm{p}$ \\
\hline \multicolumn{2}{|l|}{ Age (years) } & $15.08 \pm 1.87$ & $15.24 \pm 1.74$ & $14.82 \pm 2.02$ & 0.003 \\
\hline \multicolumn{2}{|l|}{ Weight (kg) } & $59.60 \pm 11.79$ & $57.96 \pm 9.91$ & $62.10 \pm 13.84$ & 0.000 \\
\hline \multicolumn{2}{|l|}{ Height $\left(m^{2}\right)$} & $1.65 \pm 0.09$ & $1.62 \pm 0.07$ & $1.69 \pm 0.10$ & 0.000 \\
\hline \multicolumn{2}{|l|}{ BMI $\left(\mathrm{kg} / \mathrm{m}^{2}\right)$} & $21.93 \pm 3.47$ & $22.10 \pm 3.36$ & $21.66 \pm 3.63$ & ns \\
\hline \multicolumn{2}{|c|}{ Birthweight (BW) (kg) } & $3.31 \pm 0.55$ & $3.25 \pm 0.52$ & $3.39 \pm 0.59$ & 0.001 \\
\hline \multicolumn{2}{|c|}{ Cardiorepiratory Fitness (CRF) (laps) } & $41.28 \pm 20.22$ & $31.34 \pm 12.12$ & $56.52 \pm 20.66$ & 0.000 \\
\hline \multicolumn{2}{|c|}{ Father BMI $\left(\mathrm{kg} / \mathrm{m}^{2}\right)$} & $26.64 \pm 3.33$ & $26.59 \pm 3.32$ & $26.71 \pm 3.36$ & ns \\
\hline \multicolumn{2}{|c|}{ Mother BMI (kg/m²) } & $25.59 \pm 3.95$ & $25.81 \pm 4.00$ & $25.26 \pm 3.85$ & ns \\
\hline \multirow{3}{*}{ BMI (\%) } & Normal Weight & 73.2 & 73.4 & 73 & \multirow{3}{*}{ ns } \\
\hline & Overweight & 21.4 & 21.2 & 21.9 & \\
\hline & Obese & 5.3 & 5.5 & 5.1 & \\
\hline \multirow{2}{*}{ CRF (\%) } & Under Health Zone & 44.3 & 49.9 & 35.7 & \multirow{2}{*}{$p \leq 0.05$} \\
\hline & Health Zone and Above & 55.7 & 50.1 & 64.3 & \\
\hline \multirow{3}{*}{ P-BMI (\%) } & Two parents with Normal Weight & 31.5 & 32.4 & 30 & \multirow{3}{*}{ ns } \\
\hline & At least one parent with OV/OB & 53.7 & 53.6 & 53.9 & \\
\hline & Two parents with OV/OB & 14.8 & 14 & 16 & \\
\hline \multirow{3}{*}{ P-Edu (\%) } & Low Education & 57.0 & 58.9 & 54.0 & \multirow{3}{*}{ ns } \\
\hline & Middle Education & 23.7 & 23.3 & 24.4 & \\
\hline & High Education & 19.3 & 17.8 & 21.5 & \\
\hline
\end{tabular}

BMI - Body Mass Index; CRF - Cardiorepiratory Fitness; P-BMI - Parental BMI; P-Edu - Parental Education; OV/OB - Overweighy/Obese ns $-p>0.05$ 
Table 2 - Mean and SD of adolescents and parents characteristics by BMI category within each sex

\begin{tabular}{|c|c|c|c|c|c|c|c|}
\hline \multirow{2}{*}{\multicolumn{2}{|c|}{ Characteristics }} & \multicolumn{3}{|l|}{ Girls } & \multicolumn{3}{|l|}{ Boys } \\
\hline & & $\begin{array}{l}\text { Normal Weight } \\
(n=350)\end{array}$ & $\begin{array}{l}\text { Overweight/Obese } \\
(n=127)\end{array}$ & $\mathrm{p}$ & $\begin{array}{l}\text { Normal Weight } \\
(n=227)\end{array}$ & $\begin{array}{l}\text { Overweight/Obese } \\
(n=84)\end{array}$ & $\mathrm{p}$ \\
\hline \multicolumn{2}{|l|}{ Age (years) } & $15.32 \pm 1.71$ & $15.04 \pm 1.81$ & ns & $15.04 \pm 1.96$ & $14.25 \pm 2.10$ & 0.002 \\
\hline \multicolumn{2}{|l|}{ Weight (kg) } & $54.05 \pm 7.05$ & $68.74 \pm 8.59$ & 0.000 & $58.18 \pm 10.56$ & $72.71 \pm 15.98$ & 0.000 \\
\hline \multicolumn{2}{|l|}{ Height $\left(m^{2}\right)$} & $1.62 \pm 0.07$ & $1.61 \pm 0.07$ & ns & $1.69 \pm 0.11$ & $1.67 \pm 0.09$ & ns \\
\hline \multicolumn{2}{|l|}{ BMI $\left(\mathrm{kg} / \mathrm{m}^{2}\right)$} & $20.53 \pm 1.89$ & $26.43 \pm 2.62$ & 0.000 & $20.15 \pm 2.00$ & $25.75 \pm 3.89$ & 0.000 \\
\hline \multicolumn{2}{|c|}{ Birthweight (BW) (kg) } & $3.20 \pm 0.51$ & $3.40 \pm 0.52$ & 0.000 & $3,35 \pm 0.56$ & $3.50 \pm 0.63$ & 0.046 \\
\hline \multicolumn{2}{|c|}{ Cardiorepiratory Fitness (CRF) (laps) } & $32.80 \pm 12.00$ & $27.31 \pm 11.59$ & 0.000 & $60.88 \pm 20.05$ & $44.76 \pm 17.54$ & 0.000 \\
\hline \multicolumn{2}{|c|}{ Father BMI $\left(\mathrm{kg} / \mathrm{m}^{2}\right)$} & $26.25 \pm 3.12$ & $27.54 \pm 3.65$ & 0.000 & $26.25 \pm 3.25$ & $28.02 \pm 3.36$ & 0.000 \\
\hline \multicolumn{2}{|c|}{ Mother BMI $\left(\mathrm{kg} / \mathrm{m}^{2}\right)$} & $25.18 \pm 3.64$ & $27.57 \pm 4.41$ & 0.000 & $24.99 \pm 3.64$ & $25.96 \pm 4.31$ & 0.050 \\
\hline \multirow{3}{*}{ P-BMI (\%) } & Two parents with Normal Weight & 18.9 & 7.1 & & 21.4 & 12.7 & \multirow{3}{*}{ ns } \\
\hline & At least one parent with OV/OB & 52.9 & 46.5 & & 45.0 & 49.4 & \\
\hline & Two parents with OV/OB & 28.3 & 46.5 & $p \leq 0.05$ & 33.6 & 38.0 & \\
\hline \multirow{3}{*}{ P-Edu (\%) } & Low Education & 58.9 & 59.1 & & 54.6 & 52.4 & \multirow{3}{*}{ ns } \\
\hline & Middle Education & 22.3 & 26.0 & & 22.5 & 29.8 & \\
\hline & High Education & 18.9 & 15.0 & ns & 22.9 & 17.9 & \\
\hline
\end{tabular}

BMI - Body Mass Index; LBW - Low Birth Weight; NBW - Normal Birth Weight; HBW - High Birth Weight; PBMI - Parental BMI

ns $-p>0.05$ 


\section{Girls}

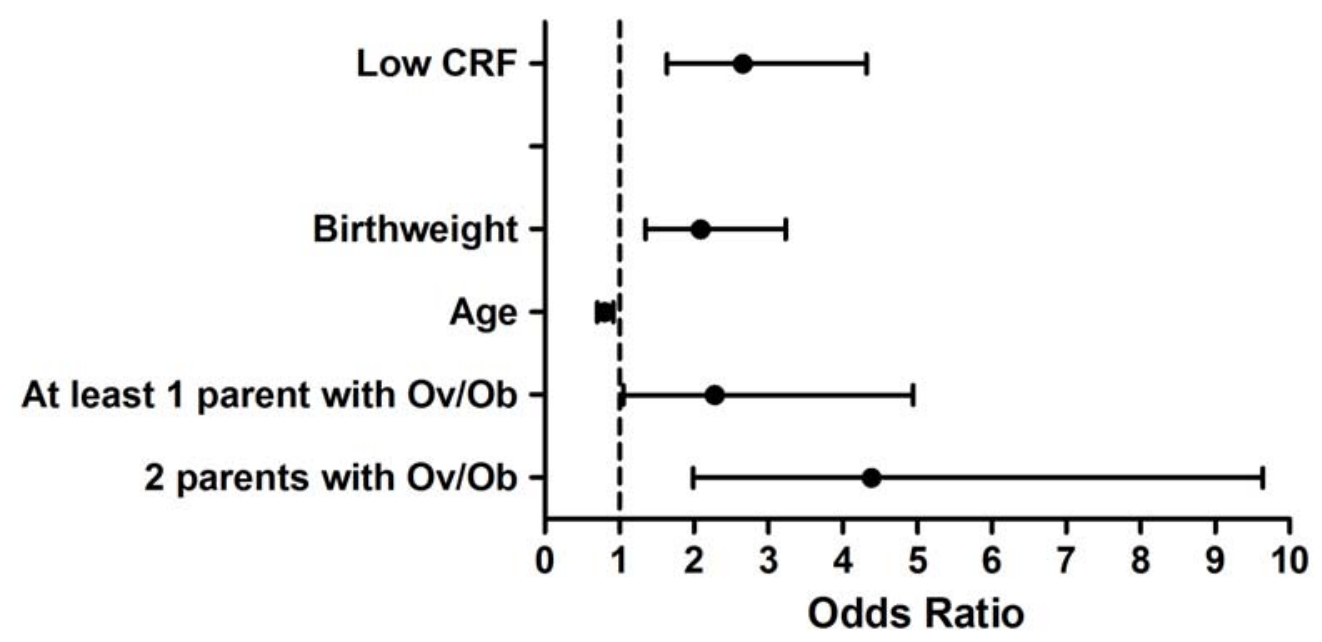

Boys

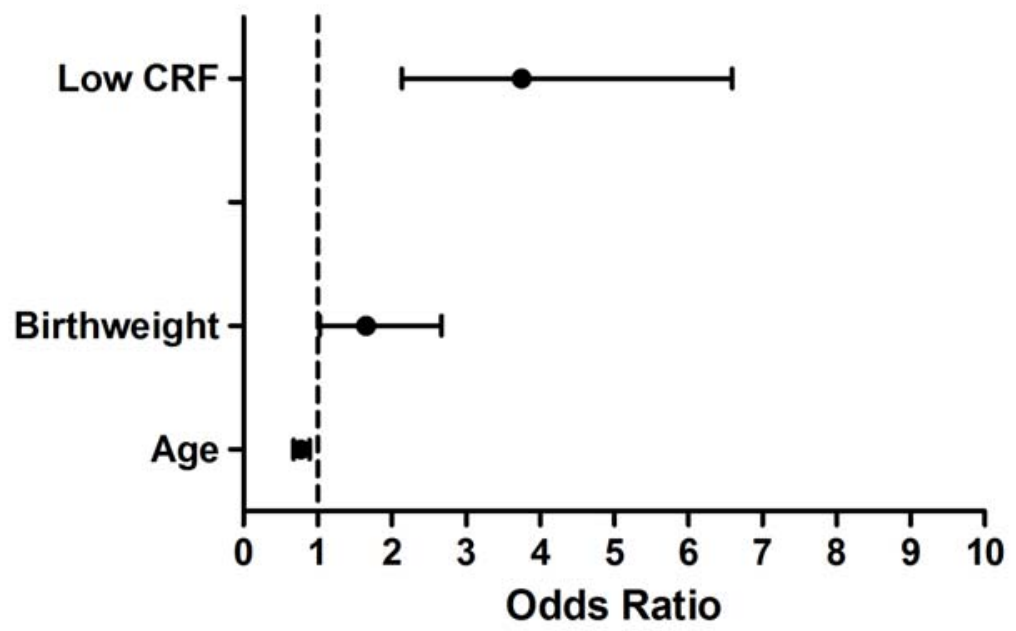

